\title{
PENILAIAN KINERJA KEUANGAN 5 PERUSAHAAN PERBANKAN TERBESAR PERIODE 2010-2012 MENGGUNAKAN DUPONT SYSTEM
}

\author{
Theresia Lesmana \\ Accounting and Finance Department, Faculty of Economic and Communication, BINUS University \\ Jln. KH Syahdan No. 9, Palmerah, Jakarta Barat 11480 \\ tlesmana@binus.edu
}

\begin{abstract}
Assessment of corporate performance can be viewed from financial aspect and nonfinancial aspect. This study attempted specifically to measure financial performance by using the DuPont system of financial analysis. DuPont system disaggregates performance into three components. They are Net Profit Margin (NPM), Return on Assets (ROA) and Return on Equity (ROE). Object of this study is five largest financial institutions based on market capitalization and go public. Those five financial institutions are Bank Republik Indonesia (Persero) Tbk (BBRI), Bank Central Asia Tbk (BBCA), Bank Mandiri (Persero) Tbk (BMRI), Bank Negara Indonesia (Persero) Tbk (BBNI) and Bank Danamon Indonesia Tbk (BDMN). The financial performance of five banks was measured for three periods, from 2010 until 2012. It was found that only Bank Negara Indonesia (Persero) Tbk is the best financial performance using DuPont System.
\end{abstract}

Keywords: DuPont system, NPM, ROA, ROE, Bank

\begin{abstract}
ABSTRAK
Penilaian kinerja suatu perusahaan dapat dilihat baik melalui aspek keuangan maupun nonkeuangan. Penelitian ini secara khusus hanya mengukur kinerja keuangan perusahaan dengan memfokuskan pada analisis sistem DuPont. Sistem DuPont membagi kinerja ke dalam tiga komponen, yakni margin laba bersih, tingkat pengembalian atas aset, dan tingkat pengembalian atas ekuitas/modal. Objek penelitian adalah lima perusahaan perbankan terbesar berdasarkan kapitalisasi pasar dan telah mencatatkan perusahaannya di bursa saham. Bank tersebut adalah Bank Republik Indonesia (Persero) Tbk (BBRI), Bank Central Asia Tbk (BBCA), Bank Mandiri (Persero) Tbk (BMRI), Bank Negara Indonesia (Persero) Tbk (BBNI), dan Bank Danamon Indonesia Tbk (BDMN). Kinerja kelima bank tersebut diukur selama tiga periode, yaitu dari 2010 hingga 2012. Hasil penelitian menunjukkan bahwa dari kelima bank tersebut hanya Bank Negara Indonesia (Persero) Tbk yang mengalami kinerja keuangan yang baik menggunakan sistem DuPont.
\end{abstract}

Kata kunci: Sistem DuPont, NPM, ROA, ROE, Bank 


\section{PENDAHULUAN}

Tujuan mendirikan suatu perusahaan antara lain ialah memaksimalkan profit, mempertahankan kelangsungan hidup perusahaan, dan memaksimalkan kesejahteraan pemegang saham. Tujuan perusahaan tersebut akan tercapai jika di dalam perusahaan terdapat manajemen perusahaan yang bermutu tinggi. Manajemen yang bermutu tinggi tersebut akan terlihat pada kemampuan mereka dalam mengelola sumber daya yang dimiliki perusahaan dan menjalankan operasional perusahaan dengan baik.

Keberhasilan pihak manajemen perusahaan tersebut diukur dari kinerja-kinerja baik dari sisi keuangan maupun dari sisi nonkeuangan. Kinerja suatu perusahaan terutama kinerja keuangannya dapat terlihat pada laporan keuangan tahunan masing-masing perusahaan. Bagi perusahaan go public, laporan keuangan tahunan akan terlebih dahulu diaudit oleh kantor akuntan publik untuk dipastikan kewajaran atas angka-angka yang tersaji di dalam laporan keuangan.

Laporan keuangan yang telah diaudit akan menjadi gambaran untuk pemegang kepentingan dalam menilai kinerja perusahaan. Untuk menilai kinerja perusahaan perlu dilakukan analisis-analisis melalui laporan keuangan. Hasil analisis tersebut akan lebih baik jika dibandingkan dari tahun-tahun sebelumnya dan dibandingkan dengan beberapa perusahaan yang bergerak dalam industri yang sama. Perbandingan analisis dari tahun-tahun sebelumnya dapat berguna dalam melihat perkembangan kinerja perusahaan tersebut jika meningkat atau menurun. Sedangkan perbandingan hasil analisis terhadap perusahaan sejenis dapat berguna untuk melihat tingkat persaingan dalam rangka mempertahankan kelangsungan perusahaan.

Bank merupakan perusahaan bisnis yang memiliki komponen aset dan liabilitas yang unik pada laporan keuangan, regulasi dan operasional yang berbeda dengan perusahaan bisnis lainnya, sehingga menjadi objek yang menarik dari penelitian ini, khususnya dalam kondisi keuangannya. Analisis kondisi keuangannya dapat dihitung dengan rasio keuangan menggunakan beberapa item di laporan keuangan sebagai sumber data awal, seperti DuPont System.

DuPont System diciptakan oleh F. Donaldson Brown dari DuPont Corporation untuk melakukan analisis keuangan General Motors. Analisis Du Pont System ini bersifat menyeluruh karena mencakup tingkat efisiensi perusahaan dalam penggunaan aktivanya dan dapat mengukur tingkat keuntungan atas penjualan produk yang dihasilkan oleh perusahaan tersebut.

Almazari (2012) meneliti tentang pengukuran kinerja keuangan pada Jordianan Arab Bank dari periode 2000-2009 dengan menggunakan DuPont System. Hasil dari penelitian tersebut menunjukkan hasil bahwa kinerja keuangan Arab Bank relatif stabil. Kinerja keuangan yang stabil tersebut dilihat dari margin laba bersih dan perputaran total aset yang juga relatif stabil untuk tahun 2001-2009. Multiplier ekuitas juga menunjukkan indikator hampir stabil untuk periode 2001 hingga 2005. Di sisi rasio, rasio keuangan perusahaan juga menurun dari 2006-2009 yang dikatakan bahwa Arab Bank terindikasi leverage financial menurun dalam beberapa tahun. Leverage yang menurun tersebut memiliki arti bahwa Arab Bank tidak terlalu bergantung pada utang untuk membiayai aset.

Tujuan dari penelitian ini adalah untuk mengukur kinerja keuangan lima perusahaan perbankan yang sudah go public dan memiliki kapitalisasi pasar terbesar dengan menggunakan pendekatan sistem DuPont periode 2010 hingga 2012. Penggunakan rasio Net Profit Margin dapat mengindikasikan seberapa efekifnya perusahaan dalam mengendalikan biaya menjadi pendapatan. Dengan menggunakan ROA, penelitian ini juga bertujuan untuk menunjukkan efisiensi perusahaan dalam menggunakan asetnya, dan melalui rasio ROE, penelitian ini dapat menunjukan keuntungan perusahaan yang diperoleh dibandingkan dengan jumlah ekuitas perusahaan. 


\section{METODE PENELITIAN}

Penelitian ini mengacu kepada lima perusahaan perbankan dari 2010-2012. Lima bank tersebut terpilih berdasarkan bank yang telah go public dan memiliki nilai kapitalisasi pasar terbesar berdasarkan idx fact book 2010-2012. Lima perusahaan perbankan tersebut adalah: Bank Republik Indonesia (Persero) Tbk (BBRI), Bank Central Asia Tbk (BBCA), Bank Mandiri (Persero) Tbk (BMRI), Bank Negara Indonesia (Persero) Tbk (BBNI), dan Bank Danamon Indonesia Tbk (BDMN). Nilai kapitalisasi merupakan perkalian antara harga saham di pasar dengan jumlah saham yang beredar. Makin besar nilai kapitalisasi pasar suatu perusahaan, makin besar pangsa pasar perusahaan di suatu industri. Metode yang digunakan dalam mengukur kinerja keuangan 5 perusahaan perbankan tersebut adalah analisis sistem DuPont. Penelitian menggunakan data sekunder yaitu memperoleh data berupa laporan keuangan tahunan lima perusahaan perbankan yang sudah tersedia di website IDX atau di masing-masing situs web perusahaan tersebut.

\section{HASIL DAN PEMBAHASAN}

Pengukuran kinerja dalam penelitian ini akan menggunakan analisis sistem DuPont. Gitman dan Zutter (2012) menganalisis laporan keuangan dan menilai kondisi atau kinerja perusahaan, khususnya kondisi keuangan dapat menggunakan pendekatan analisis sistem DuPont. Secara spesifik, pengukuran kinerja keuangan dengan sistem DuPont lebih menekankan kepada perhitungan komponen-komponen yang terdapat di dalam laporan laba rugi (income statement) dan neraca (balance sheet) perusahaan. Laporan laba rugi dan neraca tersebut akan saling berhubungan dalam mengukur profitabilitas, return on total assets (ROA), dan return on common equity (ROE).

Langkah pertama pengukuran kinerja dalam menggunakan sistem DuPont yaitu menghitung net profit margin untuk mengetahui tingkat probilitas penjualan perusahaan dan total asset turnover yang mengukur efektivitas perusahaan dalam menggunakan aset. Kedua perhitungan (net profit margin dan total asset turnover) tersebut menghasilkan DuPont formula. DuPont Formula dapat digambarkan dengan persamaan matematika, sebagai berikut.

$R O A=$ Net Profit Margin $x$ Total Asset Turnover

Persamaan tersebut dapat dijabarkan sebagai berikut.

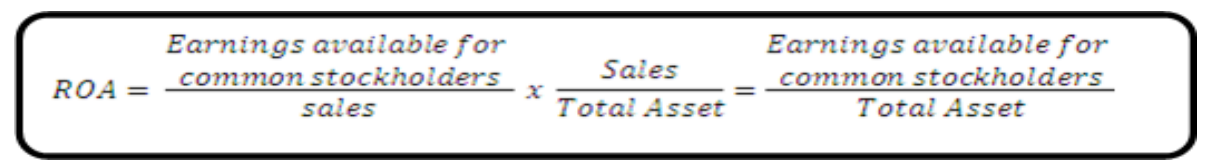

Dari rumus tersebut, Net Profit Margin menunjukkan besarnya persentase laba bersih yang dimiliki oleh perusahaan dibandingkan dengan pendapatan operasional. Hasil perhitungan dari perputaran total aset menunjukan seberapa besar pendapatan yang diperoleh perusahaan dengan aset yang dimiliki oleh perusahaan. Sehingga ROA akan berubah ketika terjadi perubahan pada naik atau turunnya profit perusahaan dan atau tingkat perputaran pada aset perusahaan. Dapat disimpulkan bahwa makin besar ROA, perusahaan tersebut makin efisien dalam menggunakan aset untuk memperoleh pendapatan.

Langkah kedua yang disebut sebagai modified DuPont Formula. Modified DuPont Formula merupakan perhitungan untuk return on common equity (ROE). ROE didapat dari perkalian antara return on total assets dengan financial leverage multiplier (FLM). FLM adalah rasio dari total aset 
yang dimiliki perusahaan terhadap modal saham biasa perusahaan. Dari perkalian ROA dan FLM tersebut, dapat disimpulkan bahwa ROE adalah seberapa besar laba bersih perusahaan dengan ekuitas yang dimiliki perusahaan. Makin besar ROE akan makin optimal pengembalian modal yang bisa dihasilkan oleh perusahaan. Persamaan ROE tersebut dapat digambarkan sebagai berikut.

$$
R O E=R O A \times F L M
$$

Persamaan tersebut dapat dijabarkan sebagai berikut.

$$
R O E=\frac{\begin{array}{l}
\text { Earnings available for } \\
\text { common stockholders }
\end{array}}{\text { Total Assets }} \times \frac{\text { Total Assets }}{\text { Common Stock Equity }}=\frac{\begin{array}{c}
\text { Earnings available for } \\
\text { common stockholders }
\end{array}}{\text { Common Stock Equity }}
$$

Perusahaan yang sumber pembiayaan lebih banyak berasal dari utang, maka akan berakibat pada tingginya multiplier ekuitas. Dengan kata lain, makin tinggi hutang, makin kecil ekuitas. Tingkat pengembalian ekuitas perusahaan tergantung kepada ROA dan penggunaan kewajiban (leverage). Rumus dari DuPont tersebut dapat digambarkan ke dalam bentuk skema. Berikut adalah skema untuk analisis sistem DuPont.

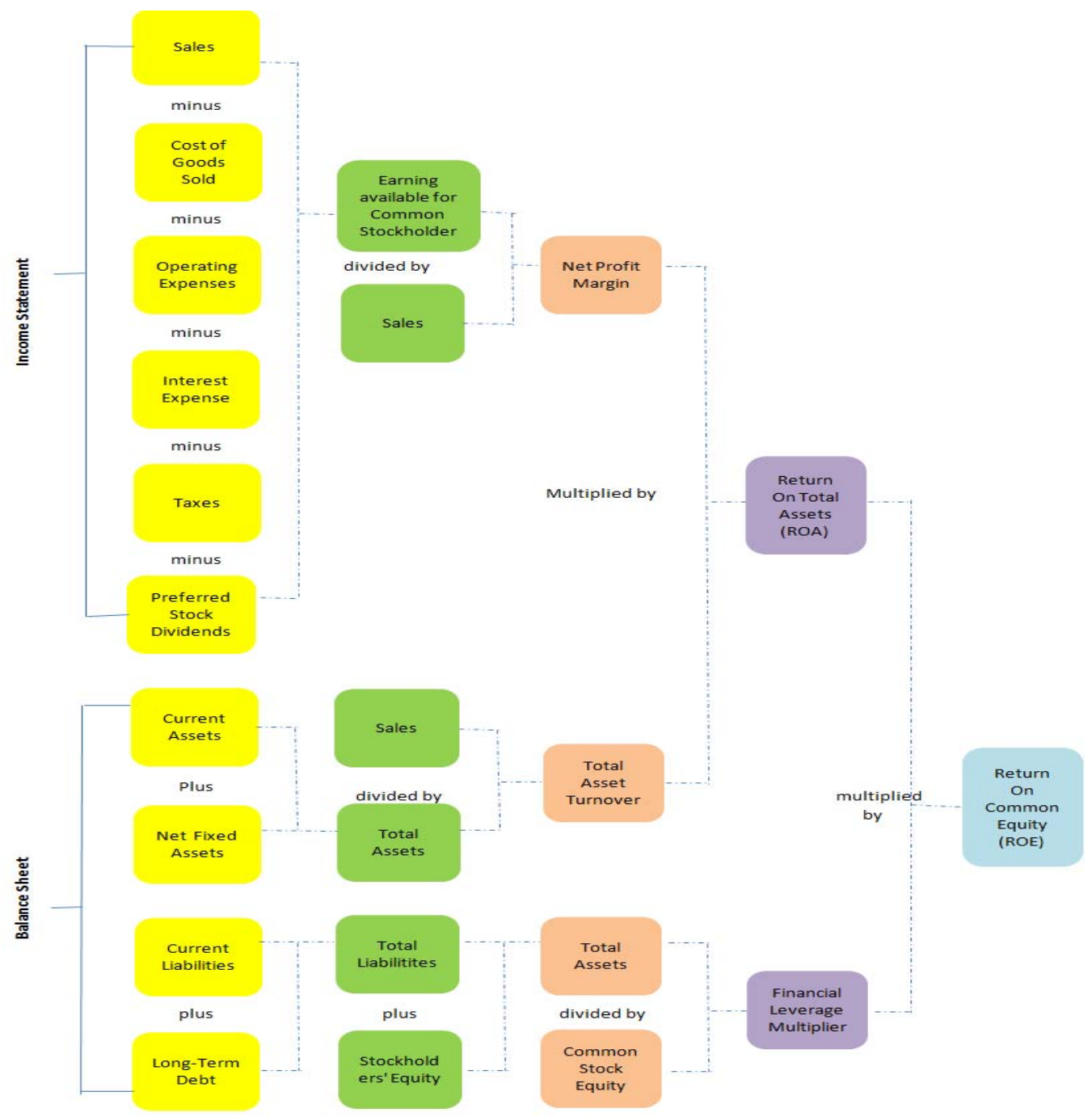

Gambar 1 Skema Sistem DuPont 
Berdasarkan uraian, selanjutnya penelitian melakukan analisis pada 5 perusahaan perbankan yaitu Bank Republik Indonesia (Persero) Tbk (BBRI), Bank Central Asia Tbk (BBCA), Bank Mandiri (Persero) Tbk (BMRI), Bank Negara Indonesia (Persero) Tbk (BBNI), dan Bank Danamon Indonesia Tbk (BDMN) untuk periode 2010-2012. Berikut adalah hasil dari perhitungan rasio masing-masing perusahaan.

Tabel 1 Bank Rakyat Indonesia (Persero) Tbk (BBRI)

\begin{tabular}{crrrll}
\hline \multirow{2}{*}{ Ratio } & \multicolumn{3}{c}{ Year } & \multirow{2}{*}{ Kondisi } & \multirow{2}{*}{ Keterangan } \\
\cline { 2 - 4 } & $\mathbf{2 0 1 0}$ & \multicolumn{1}{c}{$\mathbf{2 0 1 1}$} & $\mathbf{2 0 1 2}$ & & \\
\hline NPM (\%) & 25.71 & 31.76 & 37.66 & Meningkat & Semakin Baik \\
ROA (\%) & 3.69 & 3.99 & 4.33 & Meningkat & Semakin Baik \\
ROE (\%) & 40.65 & 37.65 & 36.77 & Menurun & Semakin Buruk \\
\hline
\end{tabular}

Tabel 2 Bank Central Asia Tbk.

\begin{tabular}{crrrrl}
\hline \multirow{2}{*}{ Ratio } & \multicolumn{3}{c}{ Year } & \multirow{2}{*}{ Kondisi } & \multirow{2}{*}{ Keterangan } \\
\cline { 2 - 4 } & $\mathbf{2 0 1 0}$ & \multicolumn{1}{c}{$\mathbf{2 0 1 1}$} & \multicolumn{1}{c}{$\mathbf{2 0 1 2}$} & & \\
\hline NPM (\%) & 41.04 & 43.84 & 40.74 & Naik - Turun & Tidak Stabil \\
ROA (\%) & 3.28 & 3.57 & 2.44 & Naik - Turun & Tidak Stabil \\
ROE (\%) & 31.23 & 32.40 & 21.13 & Naik - Turun & Tidak Stabil \\
\hline
\end{tabular}

Tabel 3 Bank Mandiri (Persero) Tbk. (BMRI)

\begin{tabular}{crrrll}
\multirow{2}{*}{ Ratio } & \multicolumn{3}{c}{ Year } & \multirow{2}{*}{ Kondisi } & \multirow{2}{*}{ Keterangan } \\
\cline { 2 - 4 } & $\mathbf{2 0 1 0}$ & $\mathbf{2 0 1 1}$ & \multicolumn{1}{c}{$\mathbf{2 0 1 2}$} & & \\
\hline NPM (\%) & 27.17 & 33.08 & 38.21 & Meningkat & Semakin Baik \\
ROA (\%) & 3.11 & 2.99 & 3.23 & Turun-Naik & Tidak Stabil \\
ROE (\%) & 33.63 & 26.35 & 26.79 & Turun-Tetap & Tidak Stabil \\
\hline
\end{tabular}

Tabel 4 Bank Negara Indonesia (Persero) Tbk. (BBNI)

\begin{tabular}{rrrrrl}
\hline \multirow{2}{*}{ Ratio } & \multicolumn{3}{c}{ Year } & \multirow{2}{*}{ Kondisi } & \multirow{2}{*}{ Keterangan } \\
\cline { 2 - 4 } & $\mathbf{2 0 1 0}$ & \multicolumn{1}{c}{$\mathbf{2 0 1 1}$} & \multicolumn{1}{c}{$\mathbf{2 0 1 2}$} & & \\
\hline NPM (\%) & 21.77 & 28.95 & 31.72 & Meningkat & Semakin Baik \\
ROA (\%) & 2.21 & 2.49 & 2.67 & Meningkat & Semakin Baik \\
ROE (\%) & 16.56 & 19.72 & 20.45 & Meningkat & Semakin Baik \\
\hline
\end{tabular}

Tabel 5 Bank Danamon Indonesia Tbk. (BDMN)

\begin{tabular}{|c|c|c|c|c|c|}
\hline \multirow{2}{*}{ Ratio } & \multicolumn{3}{|c|}{ Year } & \multirow{2}{*}{ Kondisi } & \multirow{2}{*}{ Keterangan } \\
\hline & 2010 & 2011 & 2012 & & \\
\hline NPM (\%) & 20.00 & 20.43 & 21.65 & Meningkat & Semakin Baik \\
\hline ROA (\%) & 3.39 & 3.25 & 3.52 & Turun-Naik & Tidak Stabil \\
\hline ROE (\%) & 21.69 & 17.85 & 19.10 & Turun-Naik & Tidak Stabil \\
\hline
\end{tabular}

Hasil rasio dari masing-masing bank kemudian digabungkan dan dianalisis. Penggabungan rasio dari masing-masing bank tersebut adalah sebagai berikut. 
Tabel 6 Penggabungan Rasio 5 Perusahaan Perbankan

\begin{tabular}{lccccccccc}
\hline & \multicolumn{3}{c}{ NPM } & & & ROA & \multicolumn{3}{c}{ ROE } \\
\cline { 2 - 11 } & $\mathbf{2 0 1 0}$ & $\mathbf{2 0 1 1}$ & $\mathbf{2 0 1 2}$ & $\mathbf{2 0 1 0}$ & $\mathbf{2 0 1 1}$ & $\mathbf{2 0 1 2}$ & $\mathbf{2 0 1 0}$ & $\mathbf{2 0 1 1}$ & $\mathbf{2 0 1 2}$ \\
\hline BBRI & $25.71 \%$ & $31.76 \%$ & $37.66 \%$ & $3.69 \%$ & $3.99 \%$ & $4.33 \%$ & $40.65 \%$ & $37.65 \%$ & $36.77 \%$ \\
BBCA & $41.04 \%$ & $43.84 \%$ & $40.74 \%$ & $3.28 \%$ & $3.57 \%$ & $2.44 \%$ & $31.23 \%$ & $32.40 \%$ & $21.13 \%$ \\
BMRI & $27.17 \%$ & $33.08 \%$ & $38.21 \%$ & $3.11 \%$ & $2.99 \%$ & $3.23 \%$ & $33.63 \%$ & $26.35 \%$ & $26.79 \%$ \\
BBNI & $21.77 \%$ & $28.95 \%$ & $31.72 \%$ & $2.21 \%$ & $2.49 \%$ & $2.67 \%$ & $16.56 \%$ & $19.72 \%$ & $20.45 \%$ \\
BDMN & $20.00 \%$ & $20.43 \%$ & $21.65 \%$ & $3.39 \%$ & $3.25 \%$ & $3.52 \%$ & $21.69 \%$ & $17.85 \%$ & $19.10 \%$ \\
\hline
\end{tabular}

Net profit margin (NPM) menunjukkan persentase besarnya laba bersih yang diperoleh suatu bank dibandingkan dengan pendapatan operasionalnya. Dapat dilihat dari tabel bahwa NPM untuk Bank Republik Indonesia, Bank Mandiri, Bank Negara Indonesia dan Bank Danamon Indonesia mengalami kenaikan dari 2010-2012. Sedangkan untuk Bank Central Asia net profit margin mengalami penurunan sebesar 3.1\% ke tahun 2012. Sehingga dari NPM tersebut, dapat diidentifikasikan bahwa bank yang paling efisien dalam mengelola biaya menjadi pendapatan adalah Bank BCA. Bank BCA memiliki rasio NPM terbesar selama 3 tahun dari kelima bank lainnya.

ROA sangat berguna dalam memberikan informasi mengenai seberapa besar persentase laba bersih bila dibandingkan dengan total aset yang dimiliki oleh bank. Makin tinggi ROA, makin baik bank tersebut karena menunjukan pertumbuhan laba yang baik bagi bank tersebut. Berdasarkan tabel, ada 2 bank yang mengalami kenaikan ROA sampai 2012, yaitu BRI dan BNI. Serta ada 3 bank yang mengalami penurunan di tahun 2011 namun kembali meningkat di tahun 2012, bank tersebut adalah BCA, Bank Mandiri, dan Bank Danamon. Dari hasil yang didapat, Bank yang paling efisien dalam mengolah asetnya adalah Bank Rakyat Indonesia. Bank Rakyat Indonesia memiliki rasio ROA tertinggi selama 3 tahun dari keempat bank lainnya.

Salah satu rasio dalam menggunakan sistem DuPont ini yaitu ROE. ROE (Return on Equity) yaitu salah satu rasio untuk mengukur tingkat profitabilitas suatu perusahaan. ROE digunakan untuk melihat seberapa besar laba bersih bank dibandingkan dengan ekuitas yang dimiliki oleh bank. Untuk BRI dan BCA tingkat ROE tersebut mengalami penurunan dari 2010-2012. Kemudian untuk Bank Mandiri dan Bank Danamon Indonesia, ROE mengalami penurunan dari 2010-2011 namun kembali meningkat pada 2012. Berbeda dengan tingkat ROE di BNI yang mengalami kenaikan dari 2011-2012. Bank yang memiliki ROE tertinggi selama 3 tahun yaitu Bank Rakyat Indonesia. Posisi kedua adalah Bank Central Asia, ketiga adalah Bank Mandiri, keempat Bank Nasional Indonesia, dan terakhir adalah Bank Danamon.

\section{SIMPULAN}

Berdasarkan hasil penelitian yang sudah dilakukan, maka penelitian menyimpulkan sebagai berikut. Pertama, untuk mengukur kinerja keuangan dengan menggunakan DuPont System, dapat digunakan tiga rasio yang berkaitan, yakni: net profit margin, return on asset, dan return on equity. Kedua, dari aspek Net Profit Margin (NPM), maka BRI, Bank Mandiri, BNI, dan Bank Danamon menunjukkan tingkat kinerja keuangan yang makin baik, yakni mengalami peningkatan dari tahun ke tahun. Sedangkan untuk BCA, tingkat kinerja dalam Net Profit Margin mengalami ketidakstabilan. Namun walaupun BCA mengalami ketidakstabilan penurunan dari 2011-2012, BCA tetap memiliki NPM tertinggi di antara kelima perusahaan. Ketiga, dari aspek Return on Assets (ROA), BRI dan BNI yang meunjukkan kinerja keuangan yang makin baik. Untuk ketiga bank lainnya, yaitu BCA, Mandiri, dan Bank Danamon mengalami ROA yang tidak stabil. Dari hasil perhitungan yang ada, dapat terlihat bahwa Bank Rakyat Indonesia paling efisien dalam mengelola aset untuk mendapatkan profit. Keempat, dari aspek Return on Equity (ROE), BRI menunjukkan tingkat kinerja yang makin memburuk dari tahun 
ke tahun. Sedangkan BCA, Bank Mandiri, dan Bank Danamon menunjukkan tingkat kinerja yang tidak stabil. Sementara hanya BNI yang menunjukkan tingkat kinerja keuangan yang makin baik dari 20102012. Dari hasil perhitungan yang ada, dapat terlihat bahwa Bank Rakyat Indonesia paling efisien dalam mengelola modal yang dimiliki untuk mendapatkan profit. Kelima, secara keseluruhan, kinerja keuangan dengan menggunakan aspek rasio pada DuPont system yang menunjukkan kinerja keuangan yang terbaik adalah Bank Rakyat Indonesia yang memiliki ROA dan ROE tertinggi selama 3 tahun berturut-turut. Sementara untuk peringkat kedua yaitu Bank Central Asia (BCA).

\section{DAFTAR PUSTAKA}

Almazari, A. A. (2012). Financial Performance Analysis of the Jordanian Arab Bank by Using the DuPont System of Financial Analysis. International Journal of Economics and Finance, 4(4), 86-94.

Bursa Efek Indonesia. (n.d). Factbook. Diakses 11 Mei 2013 dari http://www.idx.co.id/idid/beranda/publikasi/factbook.aspx.

Gitman, L. J., and Zutter, C. J. (2012). Principle of Managerial Finance 13rd edition. United States: Prentice Hall.

Ross, S. A., et. al. (2007). Modern Financial Management. New York: McGraw Hill. 